\title{
Antiulcer protective activity of gum \\ Arabic (Acacia Senegal) in adult rats
}

\author{
Abeer A Khedr \\ Department of Nutrition and Food Sciences, Faculty of Home Economics, \\ Menufia University, Egypt.
}

\section{ABSTRACT}

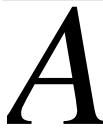

rabic Gum (AG) is an edible, and has a complex chemical composition. In folk medicine, $A G$ has been reported to be used internally for the

treatment of inflammation of the intestinal mucosa, and externally to cover inflamed surfaces. It has been claimed to act as an antioxidant. The objective of this study were assessed the protective activity of Arabic gum on against peptic ulcer which induced by ethyl alcohol in adult male rats and its application in bakery product. Forty rats were randomly divided into five groups ( $n=8$ for each), the first and second groups fed standard diet, the third, fourth and fifth groups fed standard diet containing 2.5, 5, 10\% Arabic gum powder (AGP) respectively. At the last day of experimental period (28th day), the rats were fasted for $24 \mathrm{~h}$ with free access to water. The rats of second, third, fourth and fifth groups were received a single orally dose of ethyl alcohol $90 \%$ at $10 \mathrm{ml} / \mathrm{kg}$ body weight. After one hour later and under anesthesia by diethyl ether, abdominal wall was opened, the pylorus identified, stomachs ligated from esophageal opening, removed, opened at greater curvature, gastric juice collected and centrifuged for studying of gastric secretion parameters. Also, AGP was used to replace part of the whole wheat flour $(0 \%, 2.5 \%, 5 \%$ and $10 \%)$ in standard bread. Appearance, taste, flavor, texture, , color and overall acceptability were evaluated in bread. The results showed that groups which treatment with AGP was significantly decreased in ulcer score, ulcer index and increase in preventive index compared with the positive control group. Supplemented rats diet with $10 \%$ of AGP was more effective to protect the stomach of ulcer. Moreover sensory evaluation showed that all replacement of GAP in bread was showed acceptable by the panelists. It conclude that Arabic gum had a protective activity against peptic ulcer in adult rats which induced by ethyl alcohol.

Key words: Arabic gum powder - peptic ulcer - ethyl alcohol ulcer score gastric juice - bread 


\section{INTRODUCTION}

Ulcers are most common on the skin of the lower extremities and in the gastrointestinal tract, although they may be encountered at almost any site. There are many types of ulcer such as mouth ulcer, esophagus ulcer, peptic ulcer, and genital ulcer (Debjit et al., 2010).

Peptic ulcer is a major health hazard both in terms of morbidity and mortality. The two most common types of peptic ulcer are called "gastric ulcer" and "duodenal ulcer." The name refers to the site of ulceration. Many factors, such as non- steroidal antiinflammatory drugs, helicobacter pylori, alcohol abuse, bile salts and acidifying salts are reported to change the gastroduodenal mucosal defense with subsequent development of peptic ulcer. Also, stress, cigarette smoking and spices are known to be contributing causative factors for peptic ulcer development (Yuan et al., 2006). Symptoms of peptic ulcer include nausea, vomiting and weight loss (Vyawahare et al., 2009). In some cases, peptic ulcer can be life threatening with symptoms like bloody stool, severe abdominal pain, and cramps along with vomiting blood. The World Health Organization (WHO) has listed more than 21,000 plants, which are used for many medicinal purposes around the world (Kathe, 2005).

Arabic Gum (AG) is defined as the natural secretion from stems and branches of Hashab tree (Acacia Senegal) (JECFA, 1990). Arabic Gum is a branched chain complex polysaccharide, either neutral or slightly acidic, found as a mixed calcium, 
magnesium, and potassium salt of a poly saccharide acid (Ali et al., 2009). It can be considered as an arabinogalactan containing less than $5 \%$ glycoprotein (Codipilly et al., 2006).

AG is used widely as an additive in food materials e.g. confectionery, ice-cream industries and bakery products. It is classified as an edible coating and it is used to increase stability and shelf-life and to enhance microbial safety of fruits (Roony, 2005). Gum arabic is reported to prevent development of indomethacin induced gastric ulcers in rats (Gohar and Zaki, 2014).

Also it is reputed in Arabian medicinal practices to be useful in treating patients with chronic renal failure. Additionally, AG is reported to possess antioxidant (Trommer and Neubert, 2005) and Gado and Aldahmash, 2013) renal protective (Ali et al., 2015 and Nasir, 2013)) and antidiabetic effects (Nasir et al., 2010). Therefore, the present investigation aims to evaluate the anti-ulcerogenic protective activity of gum arabic in adult male rats and its application in food.

\section{Materials and Methods}

\section{Materials:}

Arabic Gum (Acacia Senegal) was purchased from Hraz - Cario - Egypt. Ethyl alcohol (90\%), FolinCiocalteu phenol reagent, gallic acid were purchased from Sigma-Aldrich Inc. (St. Louis, MO, USA). All other chemicals were obtained from El - Gomhoreya Company, Cairo, Egypt.

\section{Preparation of Arabic gum Arabic Gum were milled by (Moulinex miller, France) to be a fine powder.}

Determination of chemical analysis of gum Arabic: 
Arabic Gum were milled by (Moulinex miller, France) to be a fine powder. Sample of the prepared gum arabic was taken for estimating its chemical composition (moisture, protein, fat, ash, total sugars, some sugars and polysaccharide, using the methods of A.O.A.C (2012). Total phenolic content expressed as gallic acid equivalent (GAE) was determined by the FolinCiocalteu micro-method according to Saeedeh and Asna, (2007). Total flavonoids content expressed as quercetin equivalent $(\mathrm{QE})$ was determined by the method of Ordon et al., (2006).

\section{Animals:}

Forty adult male Sprague Dawley rats, with an average body weight 195 $200 \mathrm{~g}$ were purchased from the Veterinary Medicine Institute, Cairo, Egypt. Under normal laboratory conditions, with 12-hours light-dark cycle at $25 \pm 1^{\circ} \mathrm{C}$, rats were housed in cylindrical wire cages with wire bottoms. The diet was introduced to rats in special food cups to avoid scattering of food. Also, water was provided to the rats by glass tube projection through the wire cage. Food and water provided and checked daily. Rats were fed standard diet according to AIN-93 guidelines (Reeves et al., 1993). All animals received care in compliance with the Egyptian rules for animal protection.

\section{Experimental groups:}

Rats were randomly divided into five groups $(\mathrm{n}=8$ for each), the first and second groups fed standard diet. The third, fourth and fifth groups fed standard diet containing 2.5, 5, 10\% of Arabic gum powder (AGP) respectively. At the last day of experimental period (28th day), the rats were fasted for $24 \mathrm{~h}$ with free access to 
water. The rats of second, third, fourth and fifth groups were received a single orally dose of ethyl alcohol at 10 $\mathrm{ml} / \mathrm{kg}$ body weight (Huang et al., 2014) to induce gastric ulceration for $2 \mathrm{~h}$. And the first group (a negative control group) received a single orally dose of saline $(0.9 \%, w / v)$.

\section{Collection of gastric} secretion and determine ulcer index:

After administration of ethyl alcohol to animals at two hour later and under anesthesia, Abdominal wall was opened, the pylorus identified, stomachs ligated from esophageal opening and removed, opened at greater curvature, gastric juice collected and centrifuged for studying of gastric secretion parameters including volume in (ml), titratable acidity, Meq/L, titratable acid output $\mathbf{M E q} / \mathbf{h}$. Stomach examined for ulceration. Evaluation of degree of ulceration was expressed in terms of ulcer score which is calculated by dividing the total number of ulcers in each group by number of rats in that group (Robert et al., 1968). Ulcer index (U.I) was calculated by multiplying ulcer score $\mathrm{x}$ 100 (Radwan et al., 2003), the ulceration (\%) was calculated by dividing the number of animals with ulcer by the total number of animals and multiplying by hundred (Ohara et al., 1992) and the preventive index was calculated according to the method of Hano et al. (1976).

Determination of titratable acidity and $p H$ value of gastric secretion

$0.2 \mathrm{ml}$ of centrifuged gastric juice was titrated using phenol red as an indicator with end point at $7.0 \mathrm{pH}$ against $0.01 \mathrm{NaOH}$. Titratable acidity was calculated in Meq/L. Total titratable acid output 
Meq/L amount of $\mathrm{NaOH}$ that neutralize $100 \mathrm{mg}$ of gastric juice (Deverport, 1972), $\mathrm{pH}$ value were determine according to (Debnath et al., 1974).

\section{Histopathology examinations of the stomach:}

A histopathology examination of the stomach was determined according to the method described by Banchroft et al., (1996).

\section{Preparation of bread and sensory evaluation}

Bread was prepared by mixing $100 \mathrm{~g}$ of wheat flour (82\% extraction), $0.5 \mathrm{~g}$ of active dry yeast, $1.5 \mathrm{~g}$ of sodium chloride, $75-80 \mathrm{ml}$ of water by hand for about 6 min to form the needed dough. AGP was used to replace part of the whole wheat flour $(0,2.5,5$ and 10 $\%)$ in a standard .Bread recipe. The dough was left to ferment for $1 \mathrm{~h}$ at $30^{\circ} \mathrm{C}$ and was then divided into $125 \mathrm{~g}$ pieces. The pieces were arranged on a wooden board that had been sprinkled with a fine layer of bran and were left to ferment for about 45 min at the same temperature. The pieces of fermented dough were flattened to be about $20-\mathrm{cm}$ in diameter. The flattened loaves were proofed at $30-35^{\circ} \mathrm{C}$ for 15 min and then were baked at $400-500^{\circ} \mathrm{C}$ for $1-2 \mathrm{~min}$. The loaves were allowed to cool at room temperature for $2 \mathrm{~h}$ before for sensory evaluation (Eissa et al., 2007). Samples of bread were subjected to organoleptic tests (by fifteen judges) according to Watts et al., (1989). Judging rang for appearance, taste, flavor, texture, compressibility, color and overall acceptability was as follow, Excellent (9-10), Very good (8 -7), Good (5-6), Fair (3$4)$, Poor (1-2) and very poor (0-1).

\section{Statistical Analysis}

Results were expressed as the mean \pm SD. Data for 
multiple variable comparisons were analyzed by one-way analysis of variance (ANOVA). For the comparison of significance between groups, Duncan's test was used as a post hoc test according to the statistical package program (Artimage and Berry, 1987).

\section{RESULTS \&DISCUSSION}

Data in Table

showed proximate the major chemical constituents of gum Arabic powder. The AGP had $4.75 \%$ ash, $2.26 \%$ crude protein and $0.69 \%$ total fat. Idris et al., (1998) reported that gum arabic comprised of $31.5-2.6 \%$ protein and $12.5-16.0 \%$ moisture. The chemical composition of AG can vary with its source, the age of the trees from which it was obtained, climatic condition and soil environment (Al-Assaf et al., 2005). In the same table, gum arabic contain $73.57 \%$ fiber, $6.88 \%$ total sugar,
0.18 glucose, 1.61 galactose, 2.66 mannose and 71.06 polysaccharide. (Badreldin et al., 2008; Abdul-Hadi et al., 2010) reported that Arabic gum is a branchedchain, complex polysaccharide, either neutral or slightly acidic.

Also total phenolic compounds and flavonoids of AGP were $60.89 \mathrm{mg}$ gallic acid / $100 \mathrm{mg}$ and $18.25 \mathrm{mg}$ catechin / 100 gm respectively. These results were higher than the results obtained by El Sheikh, (2014) who reported that gum arabic contain $10 \mathrm{mg} /$ 100 gm phenolic compounds. Abdulrahman and AL-Yahya, (2016) reported that flavonoids and carbohydrates were found to be present in arabic gum.

Data in Table showed the effect of gum arabic on ulcer score, ulcer index, \% ulceration and preventive index in normal rats and rats with stomach ulcer. No ulcer score, ulcer 
index and \% ulceration in rats which received saline solution (normal group).

On the contrary, positive control group which received ethyl alcohol alone produced bleeding indicating severe gastric damage and an increase in ulcer score, ulcer index and \% ulceration than other treated group. Ko and Cho, (2000) reported that alcohol had been shown to affect the mucosal barrier and histology. These ulcer genic effects play a crucial role in altering gastric mucosal defense mechanisms.

The gastric lesion produced by ethanol induced gastric ulcers is due to stasis in gastric blood flow that leads to the development of the hemorrhage and necrosis. All these events lead to cell death and exfoliation in the surface epithelium

(Brzozowski et al.,1998). Rats which feeding AGP were effective to reduceing the ulcer scor, ulcer index, \% ulceration and the 10\% AGP was more effective. These results were similar to the results obtained by Abdulrahman and ALYahya (2016), who found that gum arabic at both tested doses orally produce significant reduction in the ulcer index.

Also, Helala et al., (2015) showed that pretreatment with AG significantly decreased the gastric lesions. And both ulcer severity and score were significantly decreased compared with the untreated group. Arabic Gum has been reported to reduce the development of indomethacin induced gastric ulcers (Gohar and Zaki, 2014).

In the same table positive control group which received ethyl alcohol alone produced reduction in preventive index, while an increase in preventive index was observed in groups which treated with Arabic 
gum and the rats which administration $10 \% \quad \mathrm{AG}$ produced a higher increase in preventive index which was $83.3 \%$.

In the same table positive control group produced reduction in preventive index. However an increase in preventive index was observed in groups treated with Arabic gum, and the rats supplemented with $10 \%$ AG produced a higher increase in preventive index which was 83.3\%. Arabic Gum is a known antioxidant and this would have contributed to its antiulcer action (Goodrum et al., (2000).

Moreover, Arabic gum contain an arabinogalactan, has been reported to possess antiulcer effect in rats (Goodrum et al., (2000). It is known to reduce development of ethanol induced gastric ulcers in rats (Cipriani et al., 2006).

Data presented in Table (3) illustrated the effect of Arabic gum on volume, $\mathrm{pH}$, tetrable acidity and total acid output of gastric juice of normal rats and rats with stomach ulcer. Negative control group was significantly lower $(\mathrm{P} \leq 0.05)$ in volume of gastric juice and higher $(\mathrm{P} \leq 0.05)$ in $\mathrm{pH}$, tetrable acidity and total acid output of gastric juice when compared to positive control group and AGP groups. However rats which treated with ethyl alcohol alone were produce an increase in volume of gastric juice and reduction in $\mathrm{pH}$, tetrable acidity and total acid output of gastric juice. High gastric acidity is known to be a factor in the etiology of peptic ulcer (ENO et al., 2004).

In current table, AGP showed improvement in reduction volume of gastric juice and increase $\mathrm{pH}$, tetrable acidity and total acid output of gastric juice of rats and the group which treated 
with $10 \%$ AGP showed more effective in improvement. These results are agreement with by some researchers Ciprianiet al., (2009 and Tanaka et al., (2010) who showed that arabinogalactan which is found in gum arabic significantly inhibited induced gastric lesions in rats.

The potential activity of $A G$ to act as a direct cytoprotective agent has been explained by Cipriani et al., (2009) who have stated that many mechanisms suggested for antiulcer effects of polysaccharides lie in their ability to bind to the mucosal surface and to function as a protective coating, by diminishing the secretory activities of acid or scavenging radicals.

Sensory evaluation of breads prepared with AGP portions are shown in Table (4) and picture (1). No significant $\quad(p>0.05)$ difference was observed appearance, flavor, texture and color between bread prepared with 2.5, 5, and $10 \%$ of AGP and control bread. However the bread prepared with $10 \%$ of AGP had lower $(\mathrm{P} \leq 0.05)$ taste, compressibility and overall acceptability than bread prepared with $0,2.5$ and $5 \%$ of GAP.

Arabic Gum is also useful in the baking industry because of its viscous and adhesive properties (ITC, 2008). KL khalifa et al., (2007) indicated that acceptable bakery products e.g. bread and pizza could be obtained using Arabic gum. Arabic Gum is used in a range of bakery products (FAO, 1995).

Microscopically, stomach of rat from negative control group (normal rats) revealed the normal histological gastric structure (Figs.1). In contrary, stomach of rats from positive control group (group which treated with ethyl alcohol 
alone) showed severe
histopathological changes
described by focal
of gastric rosis
haemorrhage, submucosa,
oedema associated with
inflammatory
infiltration (Figs.2). These
results were agree with Ko
and Cho (2000), who reported that chronic active gastritis is associated with chronic alcohol ingestion. Examined sections from $2.5 \%$ AGP group revealed focal necrosis of gastric mucosa and slight submucosal oedema (Figs.3). However, stomach of rats from group 5\% AGP group revealed no histopathological changes except slight submucosal oedema (Fig.4), whereas, other sections from this group revealed no histopathological changes (Fig. 5). These agreed with the result by Galati et al., (2001) and Ghildyal et al (2010) who showed gastro protective properties in several studies when polysaccharide was administered to rats before experimentally induced gastric ulcer.

Antiulcer effects of polysaccharides lie in their ability to bind to the mucosal surface and to function as protective coating pepsin and protecting the mucosa by increasing mucus synthesis or scavenging radicals (Cipriani et al., 2009).

\section{REFERENCES}

\section{Abdul-Hadi AH;}

Mahmoud AE and AbdelWahab HM (2010):

Effect of gum Arabic on coagulation system of albino rats. Int. J. Pharm. Tech. Res., 2: 1762-1766.

Abdulrahman AI and AL-
Yahya MA (2016).
Antiulcer activity of
gum arabic and its
interaction with
antiulcer effect of
ranitidine in rats.


Biomedical Research

2016; 27 (4): 1102-

1106.

Al-Assaf S; Phillips GO and Williams PA (2005):

Food Hydrocoll. 19

647-660.

Ali BH; Al Salam S; Al Husseni I; Kayed RR; Al Masroori N and Al Harthi T (2010).

Effects of gum arabic in rats with adenineinduced chronic renal failure. Exp Biol Med; 235:373-382.

Ali BH; Al Za'abi M; Al Shukaili A and Nemmar A (2015):

Highmobility group box-1 protein in adenine-induced chronic renal failure and the influence of gum arabic thereon. Physiol Res; 64: 147151.
Ali BH; Ziada A and Blunden G (2009):

Biological effects of gum arabic: a review of some recent research. Food Chem. Toxicol; 47:1-8

A.O.A.C. (2012):

International Official Methods of Analysis, $19^{\text {th }}$ ed., Gaithersburg.

\section{Artimage GY and Berry WG (1987). \\ Statistical Methods 7th \\ Ed. Ames, Iowa State \\ University Press, 39- 63.}

\section{Badreldin HA; Amal Z and Gerald B (2008): \\ Biological effects of gum Arabic: A review of some recent research. Food Chem. Toxicol., 47: 1-8.}

Banchroft JD; Stevens A; and Turner DR (1996): 
"Theory and Practice

of Histological

Techniques", Fourth

Ed.

Churchil

Livingstone,

NewYork, London,

San Francisco, Tokyo.

Brzozowski T; Konturek PC; Konturek SJ; Kwiecién S; Pajdo R; Brzozowska I and Hahn EG (1998):

\begin{tabular}{|c|}
\hline $\begin{array}{l}\text { Involvement } \\
\text { endogenous } \\
\text { cholecystokinin } \\
\text { somatostatin } \\
\text { gastroprotection } \\
\text { induced } \\
\text { intraduodenal } \\
\text { Clin Gastroente } \\
\text { Suppl 1: S125-3 }\end{array}$ \\
\hline
\end{tabular}

Cipriani TR; Mellinger CG; Bertolini MLC; Baggio CH; Freitas CS and Marques MCA (2009):

Gastroprotective effect of a type I arabinogalactan from soybean meal. Food

Chem; 115:687-690.

Cipriani TR; Mellinger CG; de Souza LM; Baggio CH; Freitas CS; Marques MC; Gorin PA; Sassaki GL and Iacomini M (2006):

A polysaccharide from a tea (infusion) of Maytenus ilicifolia leaves with anti-ulcer protective effects. $J$ Nat Prod; 69: 10181021.

Codipilly CN; Teichberg S and Wapnir RA (2006):

Enhancement of absorption by gum arabic in a model of gastrointestinal dysfunction. J Am Coll Nutr; 25:307-312.

\section{Debjit B; Chiranjib CK;} Tripathi K; Panka j and Sampath K K P (2010):

Recent trends of treatment and medication peptic ulcerative disorder. 
International Journal

of Pharm. Tech

Research, vol. 2, no. 1, pp. 970-980. View at Google Scholar · View at Scopus.

Debnath PK; Gode KD; Gobinda Das D and Sanyal A K (1974):

Effect of propranolol on gastric secretion in albino rats. $\mathrm{Br} J$ Pharmacol 51:213216.

Deverport, HW (1972):

The gastric mucosal barrier. J. Digestion, 5: 162.

Eissa HA; Hussein AS and Mostafa BE (2007):

Rheological properties and quality evaluation of Egyptian balady and biscuits supplemented with flours of ungerminated and germinated legume seeds or mushroom.
Pol. J. Food Nutr. Sci. 57, (4). 487-496.

EI Sheikh D M (2014):

Efficiency of using Arabic Gum and Plantago Seeds Mucilage as Edible Coating for Chicken Boneless Breast. Food Science and Quality Management. Vol.32: 28-24.

Eno A E; Azah N; Edet E $E$ and Itam E H (2004):

Induced secretion of pepsin -rich gastric juice in the rat by the crude extract from elaeophobia drupifera leaves: adual pathway mechanism. Nigerian Journal of Physiological Sciences 19(1-2): 53-59 (C)

FAO (1995):

Food and agriculture organization of the United Nations Rome, 
non-wood forest

products 6 Gums, resins

and latexes of plant origin.

Gado AM and Aldahmash BA (2013):

Antioxidant effect of Gum arabic against mercuric chlorideinduced nephrotoxicity. Drug Des Devel Ther; 7: 1245-1252.

Galati EM; Monforte MT; Tripodo MM; D'Aquino A and Mondello MR (2001):

Antiulcer activity of Opuntia ficus indica (L) Mill. (Cactaceae): ultrastructural study. $J$ Ethnopharmacol; 76: $1-9$.

Ghildyal P; Grønhaug TE; Rusten A; Skogsrud M; Rolstad B; Diallo D; Michaelsen TE; Inngjerdingen $M$ and Paulsen BS (2010):
Chemical composition and immunological activities of polysaccharides isolated from the Malian medicinal plant Syzygium guineense.. Journal of Pharmacognosy and Phytotherapy 2, 76 85.

Gohar AA and Zaki AA (2014):

Assessment of some Herbal Drugs for Prophylaxis of Peptic Ulcer. Iran J Pharm Res; 13: 1081-1086.

Goodrum LJ; Patel A; Leykam JF and Kieliszewski MJ (2000):

Gum arabic glycoprotein contains glycomodules of both extensin and arabinogalactanglycoproteins.

Phytochemistry; 54: 99-106. 
Hano J; Bogajske J; Danek

$L$ and Wantuch C, (1976):

Effect of neuroleptic on the development of gastric injury related to oxidation, stress and lipid peroxidation rats Laboratory investigation. Pol. J. Pharmacol. Pharm., 80 (8): 161-169.

Helala OK; Yousefa M M and Elnaab M (2011):

Possible protective effect of gum arabic on experimentally induced gastric ulcer in adult male albino rats: a histological and immunohistochemical study. The Egyptian Journal of Histology.

Huang C; Chen Y; Chuan Wang D; Chiu C; Lin W; Huang $C$ and Hsu $M$ (2014):

Cytoprotective Effect of American Ginseng in a Rat Ethanol Gastric Ulcer Model.
Molecules, 19, 316-

326;

Idris OHM; Williams PA and Phillips GO (1998):

Characterization of gum from Acacia senegal trees of different age and location using multidetection gel permeation chromatography. Food Hydrocoll. 12, 379388.

ITC (2008):

Arabic Gum, Market News Service (MNS), Quarterly Edition.

JECFA FAO / WHO (1990):

The Joint FAO/WHO Expert Committee on Food Additives Food and Nutrition FAO, Rome, 49, 23-25.

Kathe W (2005): 
The revision of the "WHO/IUCN/WWF guidelines on the conservation of medicinal plants": a step forward in medicinal plant conservation and sustainable use. Herbal Gram, 66: 60-61.

\section{Khalifa KL; Mohammed} AO; Ashwag M; Mustafa $M A$ and El tinay AEL (2007):

Use of Guar Gum and Gum Arabic as Bread Improvers for the Production of Bakery Products from Sorghum Flour. Food Science and Technology Research 13(4):327-331.

Ko JK and Cho CH (2000):

Alcohol drinking and cigarette smoking: a "partner" for gastric ulceration. Zhonghua Yi Xue Za Zhi
(Taipei). Dec; 63 (12): 845-54.

Nasir O; Artunc F; Wang K; Rexhepaj R; Föller M; Ebrahim A; Kempe DS; Biswas R; Bhandaru M; Walter M; Mohebbi N; Wagner CA Saeed AM And Lang F ( 2010):

Downregulation of mouse intestinal $\mathrm{Na}$ (+) - coupled glucose transporter SGLT1 by gum Arabic (Acacia Senegal). Cell Physiol Biochem; 25: 203-210.

Nasir O (2013):

Renal and extrarenal effects of gum arabic (Acacia senegal)-what can be learned from animal experiments? Kidney Blood Press Res; 37: 269-79.

\section{Ohara A S; Sugiyama H; Hoshino E; Hamajima $H$ and Goto F (1992): \\ Reduction of adverse effects}


indomethacin by antiallergic drugs in rat stomachs.

Arzneimittelforschung. , 42(9): 1115-8.

Ordon J D; Gomez M A and Vattuone M I (2006):

Antioxidant activities of Sechium edule (Jacq.) Swartz extracts. Food Chem., 97: 452458.

Radwan AG; Abdel Halem AT; Abou-Saif AM and Mabrouk M (2003):

Protective effect of thymus extract against stress induced gastric ulcer in rats. $A L-A z h a r$, M. J., 3,4: 553-562.

Reeves P G; Nielsen F H and Fahey GC (1993):

AIN-93 purified diets for laboratory rodents: final report of the American Institute of Nutrition adhoc writing committee on the reformulation of the AIN- 76 A rodent diet. J. Nutr., 123: 1939-1951.

Robert A; Nezamis JE and Philips JB (1968):

Effect of prostaglandin E1 on gastric secretion and ulcer formation in rats. J. Gastroenterol., 55: 481-487.

Roony ML (2005):

Introduction to Active Food Packaging Technology. In: Han $\mathrm{JH}$, editor. Innovations in food packaging. San Diego, Calif: Elsevier Academic press, 63-79.

\section{Saeedeh A and Asna U} (2007):

Antioxidant properties of various solvent extracts of mulberry (Morus indica L.) leaves. Food Chem., 102: 1233-1240. 
Tanaka LYA; De Oliveira A JB; Gonalves JE; Cipriani TR; De Souza LM and Marques MCA (2010):

An arabinogalactan with anti-ulcer protective effects isolated from Cereus peruvianus. Carbohydr Polym; 82:714-721.

\section{Trommer $H$ and Neubert} RH (2005):

The examination of polysaccharides as potential antioxidative compounds for topical administration using a lipid model system. Int J Pharm; 298: 153163.

Vyawahare $\quad \mathbf{N} \quad \mathrm{S}$; Deshmukh V V; Godkari $M \quad R$ and Kagathara $V$ G (2009):
"Plants with anti-ulcer activity,"

Pharmacognosy

Review, vol. 3, pp. 108-115,. View at

Google Scholar.

Watts BM; Yumaki CL; Jeffery LE and Elais LG (1989):

Basic sensory methods for food evaluation. The International Development Research Centre, Ottawa, Canada. p. 159.

Yuan Y; Padol TI and Hunt RH (2006):

Peptic ulcer disease today. Nature Clinical Practice

Gastroenterology \& Hepatology, 3 (2). 
Table (1): Major chemical constituents of Arabic gum

\begin{tabular}{|c|c|}
\hline Parameters & Gum arabic \\
\hline Moisture (g/100 ml) & $12.57 \pm 0.91$ \\
\hline fat $(\mathrm{g} / \mathbf{1 0 0} \mathrm{ml})$ & $0.69 \pm 0.17$ \\
\hline protein $(\mathrm{g} / 100 \mathrm{ml})$ & $2.26 \pm 0.29$ \\
\hline $\operatorname{ash}(\mathrm{g} / 100 \mathrm{ml})$ & $4.51 \pm 0.79$ \\
\hline Fiber $(\mathrm{g} / 100 \mathrm{ml})$ & $73.57 \pm 4.33$ \\
\hline Total sugar $(g / 100 g)$ & $6.88 \pm 0.65$ \\
\hline Glucose (g/100g) & $0.178 \pm 0.00$ \\
\hline Glactose (g/100g) & $1.61 \pm 3.33$ \\
\hline Mannose (g/100g) & $2.66 \pm 0.19$ \\
\hline Polysuccaride (g/100g) & $71.06 \pm 3.28$ \\
\hline $\begin{array}{l}\text { Total phenolics (mg gallic/100 } \\
\text { gm) }\end{array}$ & $60.89 \pm 5.13$ \\
\hline $\begin{array}{l}\text { Total Flavonoids (mg } \\
\text { catechin } / 100 \mathrm{gm})\end{array}$ & $25.67 \pm 2.42$ \\
\hline
\end{tabular}

Each value in the table is the mean \pm standard deviation of three replicates. 
Table (2): Effect of gum Arabic on ulcer score, ulcer index, \% ulceration and preventive index of normal rats and rats with stomach ulcer

\begin{tabular}{l|c|c|c|c|c}
\hline & \multirow{2}{*}{ negative } & \multicolumn{4}{|c}{ Ethyl alcohol groups } \\
\cline { 3 - 6 } & $\begin{array}{c}\text { Pontrameters } \\
\text { controup }\end{array}$ & $\begin{array}{c}\text { Positive } \\
\text { control } \\
\text { group }\end{array}$ & $\begin{array}{c}\mathbf{2 . 5 \%} \\
\text { GAP }\end{array}$ & $\begin{array}{c}\mathbf{5 \%} \\
\text { GAP }\end{array}$ & $\begin{array}{c}\mathbf{1 0 \%} \\
\text { GAP }\end{array}$ \\
\hline $\begin{array}{l}\text { Ulcer } \\
\text { score }\end{array}$ & -- & 9.5 & 5.97 & 2.33 & 0.83 \\
\hline $\begin{array}{l}\text { Ulcer } \\
\text { index }\end{array}$ & -- & 950 & 597 & 233 & 83 \\
\hline $\begin{array}{l}\text { \% } \\
\text { Ulceration }\end{array}$ & -- & 83.3 & 66.6 & 33.4 & 16.7 \\
\hline $\begin{array}{l}\text { Preventive } \\
\text { index }\end{array}$ & -- & 16.7 & 33.4 & 66.6 & 83.3 \\
\hline
\end{tabular}


Table (3): Effect of gum Arabic on volume, pH, tetrable acidity and total acid output in gastric juice of normal rats and rats with stomach ulcer

\begin{tabular}{|c|c|c|c|c|c|}
\hline \multirow[b]{2}{*}{ Parameters } & \multirow[b]{2}{*}{$\begin{array}{c}\text { negative } \\
\text { control } \\
\text { group }\end{array}$} & \multicolumn{4}{|c|}{ Ethyl alcohol groups } \\
\hline & & $\begin{array}{c}\text { Positive } \\
\text { control } \\
\text { group }\end{array}$ & $\begin{array}{l}2.5 \% \\
\text { GAP }\end{array}$ & $\begin{array}{c}\mathbf{5 \%} \\
\text { GAP }\end{array}$ & $\begin{array}{l}10 \% \\
\text { GAP }\end{array}$ \\
\hline $\begin{array}{l}\text { Volume of } \\
\text { gastric juice } \\
\text { (ml) }\end{array}$ & $\begin{array}{c}2.27^{\mathrm{d}} \pm \\
0.19\end{array}$ & $\begin{array}{c}5.70^{\mathrm{a}} \pm \\
0.58\end{array}$ & $\begin{array}{c}3.91^{\mathrm{b}} \pm \\
0.60\end{array}$ & $\begin{array}{c}3.36^{c} \pm \\
0.29\end{array}$ & $\begin{array}{c}2.9^{\mathrm{c}} \pm \\
0.36\end{array}$ \\
\hline pH & $\begin{array}{c}3.20^{\mathrm{a}} \pm \\
0.16\end{array}$ & $\begin{array}{c}1.30^{\mathrm{e}} \pm \\
0.08\end{array}$ & $\begin{array}{c}1.97^{\mathrm{d}} \pm \\
0.94\end{array}$ & $\begin{array}{c}2.49^{c} \pm \\
0.18\end{array}$ & $\begin{array}{c}2.97^{\mathrm{b}} \pm \\
0.07\end{array}$ \\
\hline $\begin{array}{l}\text { Tetrable acidity } \\
(\mathrm{Meq} / \mathrm{L})\end{array}$ & $\begin{array}{c}9.12^{\mathrm{e}} \pm \\
0.90\end{array}$ & $\begin{array}{c}15.59^{\mathrm{a}} \pm \\
1.25\end{array}$ & $\begin{array}{c}12.87^{\mathrm{b}} \pm \\
0.65\end{array}$ & $\begin{array}{l}11.55^{\mathrm{c}} \\
\pm 0.26 \\
\end{array}$ & $\begin{array}{l}10.25^{d} \\
\pm 0.65 \\
\end{array}$ \\
\hline $\begin{array}{l}\text { Total acid } \\
\text { output(Meq/1h) }\end{array}$ & $\begin{array}{c}182.4^{\mathrm{e}} \pm \\
14.05\end{array}$ & $\begin{array}{c}311.9^{\mathrm{a}} \pm \\
24.97\end{array}$ & $\begin{array}{c}257.5^{\mathrm{b}} \pm \\
13.07\end{array}$ & $\begin{array}{l}231.1^{\mathrm{c}} \\
\pm 5.21\end{array}$ & $\begin{array}{l}205.1^{\mathrm{d}} \\
\pm 12.98\end{array}$ \\
\hline
\end{tabular}

Data are expressed as mean $\pm S D$. Values within a row having different superscripts are significantly different $(p \leq 0.05)$; where the small letters indicate significant among dietary treatment groups as indicated by one-way ANOVA followed by Duncan's multiple range test $(a>b>c>d>e)$ 


\section{Table (4): Sensory evaluation of breads prepared with GAP portions.}

\begin{tabular}{c|c|c|c|c}
\hline \multirow{2}{*}{$\begin{array}{c}\text { Bread } \\
\text { Parameters }\end{array}$} & \multicolumn{4}{|c}{ GAP portions } \\
\cline { 2 - 5 } & $\mathbf{0 \%}$ & $\mathbf{2 . 5 \%}$ & $\mathbf{5 \%}$ & $\mathbf{1 0 \%}$ \\
\hline Appearance & $9.12^{\mathrm{a}} \pm$ & $9.25^{\mathrm{a}} \pm$ & $9.06^{\mathrm{a}} \pm$ & $9.06^{\mathrm{a}} \pm$ \\
& 0.35 & 0.37 & 0.49 & 0.32 \\
\hline \multirow{2}{*}{ Taste } & $9.37^{\mathrm{a}} \pm$ & $9.13^{\mathrm{a}} \pm$ & $9.25^{\mathrm{a}} \pm$ & $7.93^{\mathrm{b}} \pm$ \\
& 0.35 & 0.23 & 0.25 & 0.39 \\
\hline \multirow{2}{*}{ Flavor } & $9.43^{\mathrm{a}} \pm$ & $9.37^{\mathrm{a}} \pm$ & $9.31^{\mathrm{a}} \pm$ & $9.25^{\mathrm{a}} \pm$ \\
& 0.41 & 0.44 & 0.37 & 0.27 \\
\hline Texture & $9.63^{\mathrm{a}} \pm$ & $9.75^{\mathrm{a}} \pm$ & $9.38^{\mathrm{a}} \pm$ & $9.38^{\mathrm{a}} \pm$ \\
& 0.44 & 0.27 & 0.35 & 0.35 \\
\hline compressibility & $9.62^{\mathrm{a}} \pm$ & $9.63^{\mathrm{a}} \pm$ & $9.43^{\mathrm{a}} \pm$ & $8.06^{\mathrm{b}} \pm$ \\
& 0.44 & 0.35 & 0.41 & 0.49 \\
\hline Color & $9.38^{\mathrm{a}} \pm$ & $9.18^{\mathrm{a}} \pm$ & $9.25^{\mathrm{a}} \pm$ & $9.25^{\mathrm{a}} \pm$ \\
& 0.44 & 0.25 & 0.26 & 0.27 \\
\hline Overall & $9.25^{\mathrm{a}} \pm$ & $9.25^{\mathrm{a}} \pm$ & $9.18^{\mathrm{a}} \pm$ & $8.13^{\mathrm{b}} \pm$ \\
acceptability & 0.46 & 0.26 & 0.25 & 0.52 \\
\hline
\end{tabular}

Data are expressed as mean $\pm S D$. Values within a row having different superscripts are significantly different $(p \leq 0.05)$; where the small letters indicate significant among dietary treatment groups as indicated by one-way ANOVA followed by Duncan's multiple range test $(a>b>c>d>e)$ 


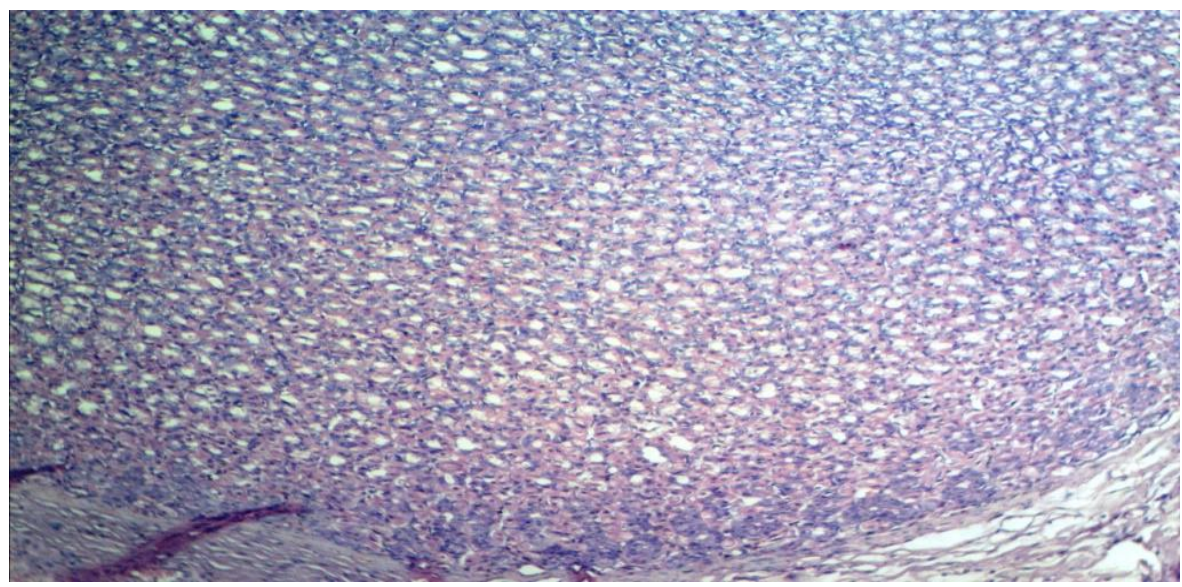

Picture (1): Stomach of rat from negative control group showing the normal histological layers (H \& E X 100)

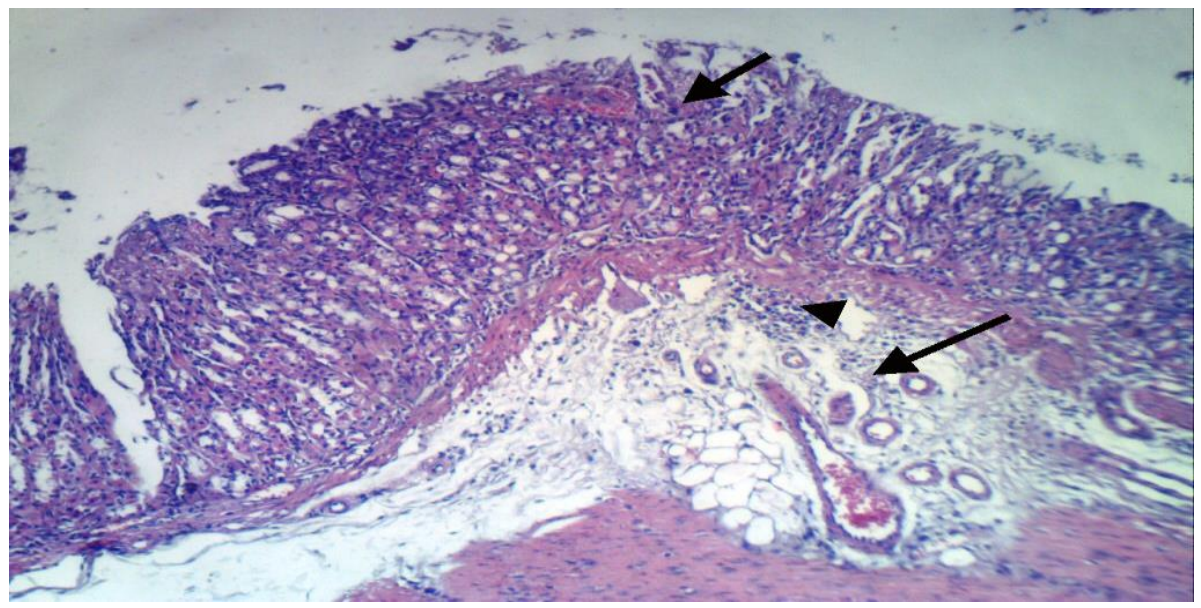

Picture (2): Stomach of rat from positive control group showing focal necrosis of gastric mucosa (small arrow), submucosal oedema (large arrow) associated with inflammatory cells infiltration (arrow head) (H \& E X 100). 


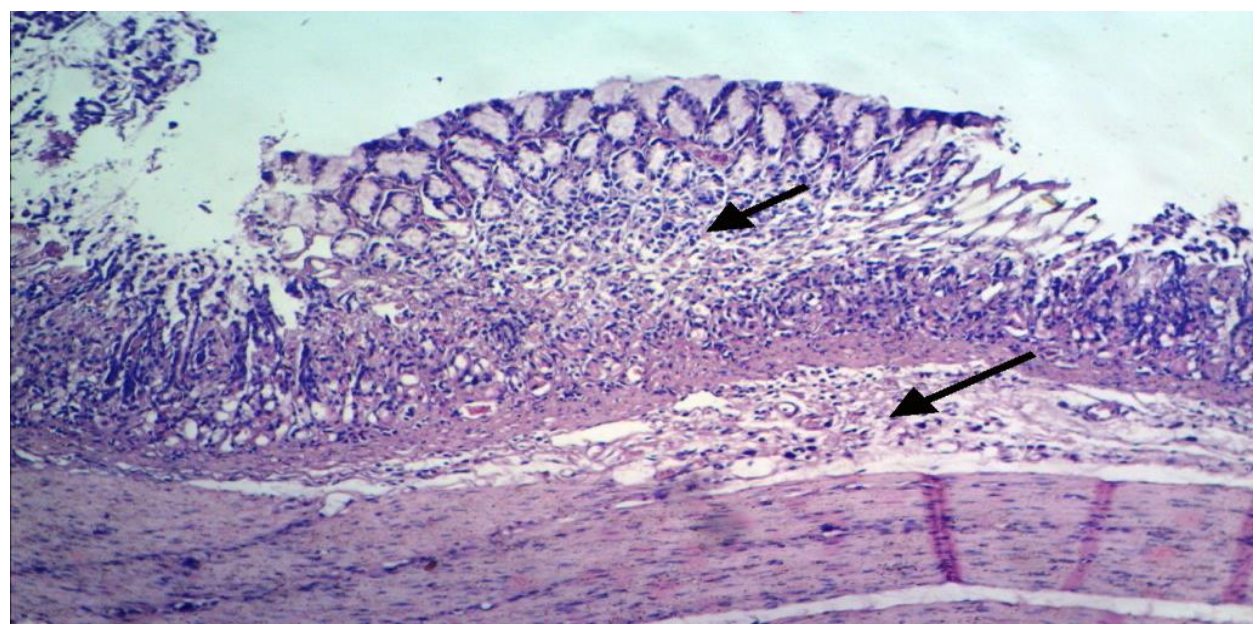

Picture (3): Stomach of rat from 2.5\% AGP group showing focal necrosis of gastric mucosa (small arrow) and slight submucosal oedema (large arrow) (H \& E X 100).

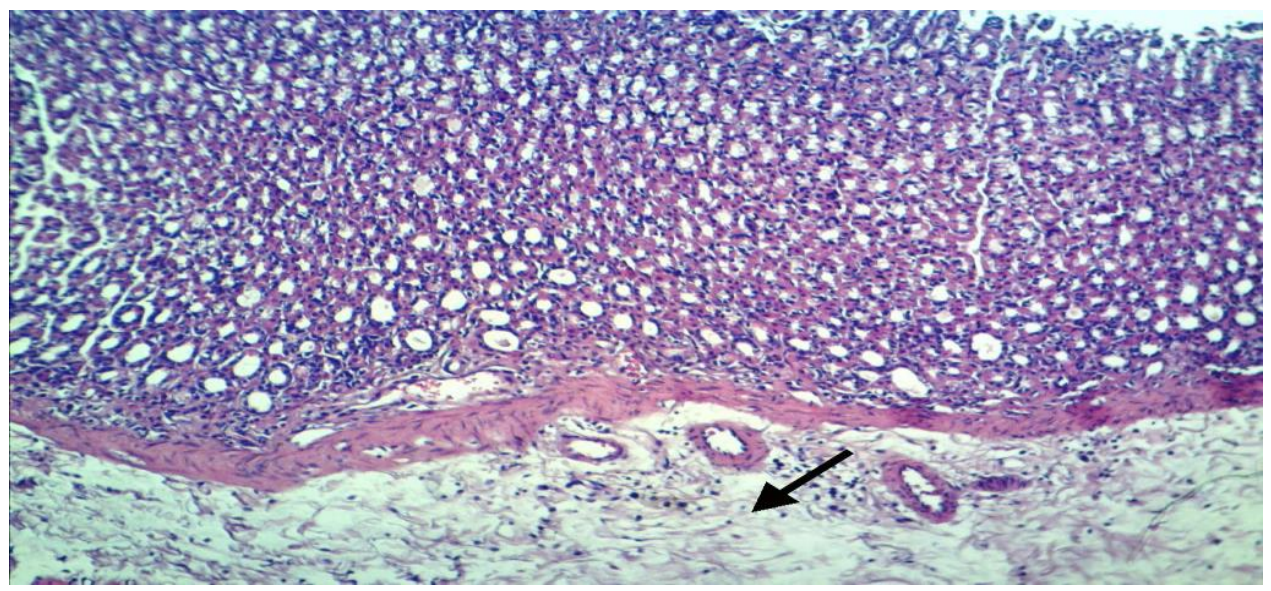

Picture (4): Stomach of rat from $10 \%$ AGP group showing slight submucosal oedema (arrow) (H \& E X 100) 


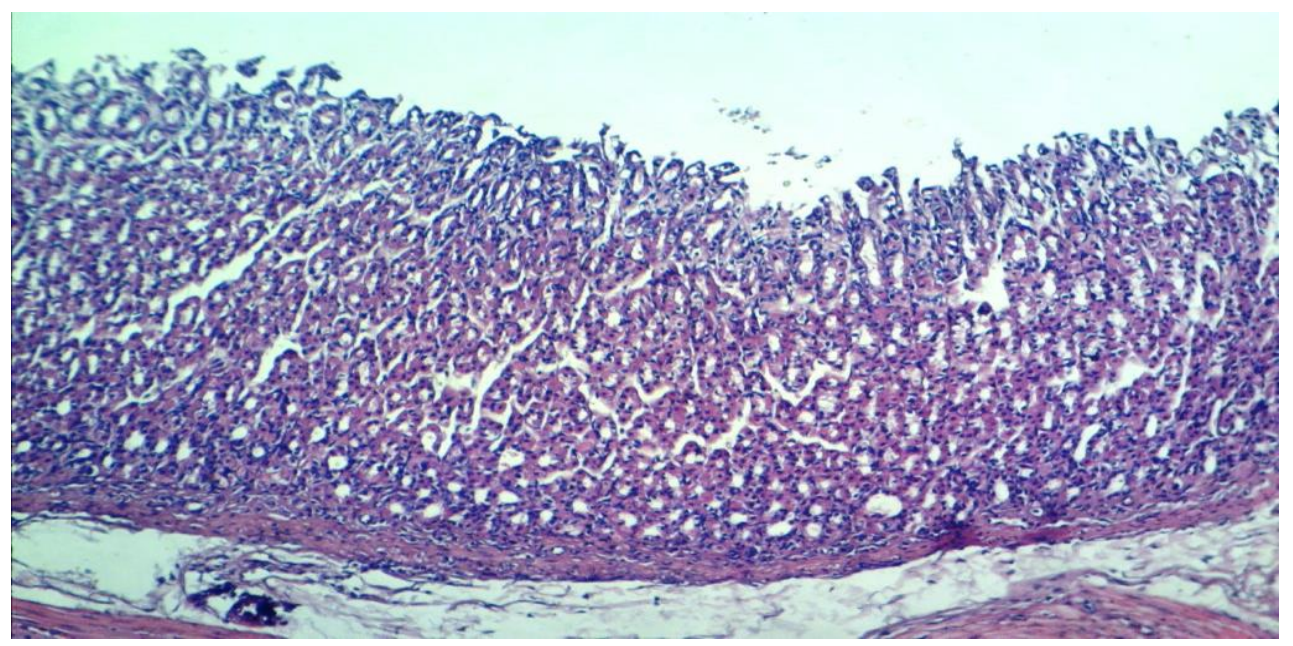

Picture (5): Stomach of rat from $10 \%$ AGP group showing no histopathological changes (H \& E X 100) 


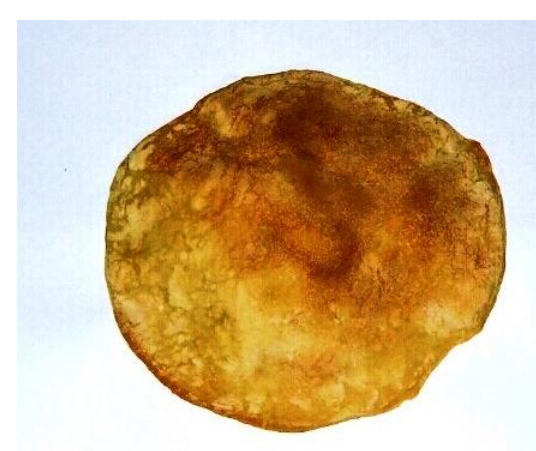

0\% GAP

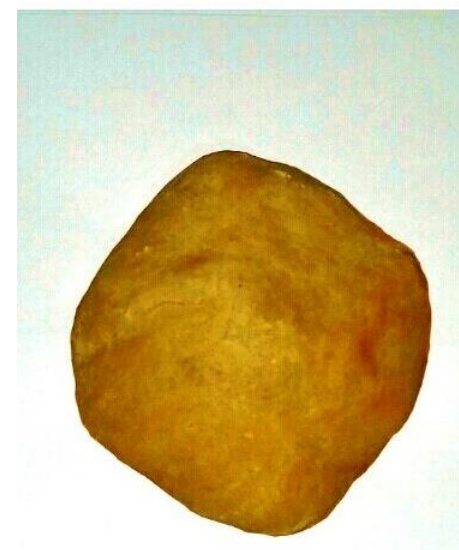

$5 \%$ GAP

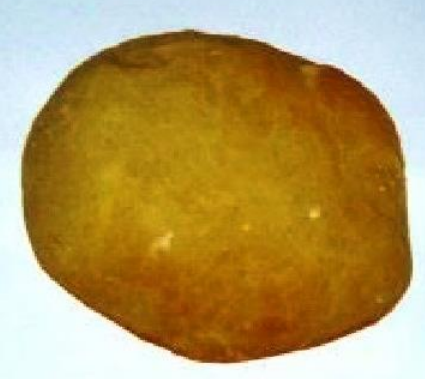

$2.5 \%$ GAP

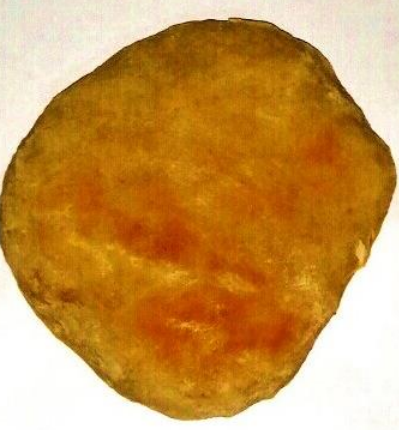

$10 \%$ GAP

Pic. (1): Flatbread supplemented with different portions with AGP. 


\section{التأثير الوقائى المضاد للقرحة للصمغ العربى فى الفي

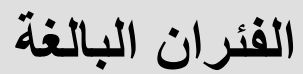 \\ عبيز أحمد خضر \\ قسم التغذية وعلوم التغذية بكلية الاقتصاد المنزلي جامعة المنوفية، شبين الكوم، مصر}

الملخص العربى المبر

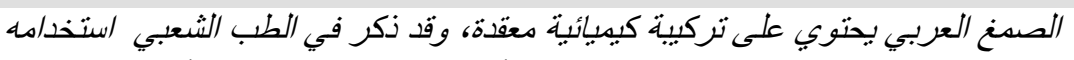

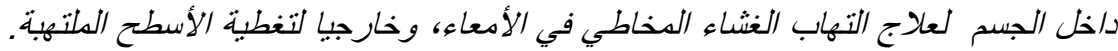

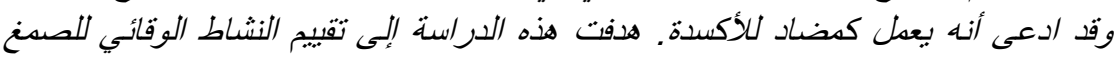

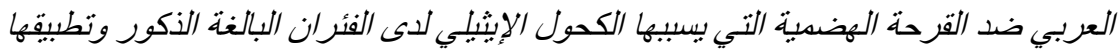

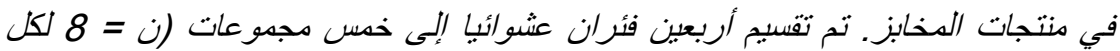

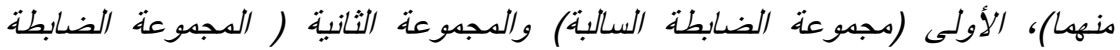

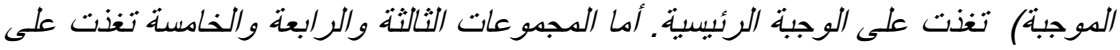
الوجبة الاساسية و 2.5، 5، 10٪ من مسحوق الصدغ العربي على العلى التوالي. في اليوم

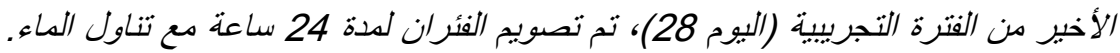

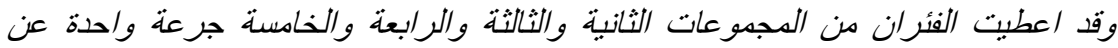

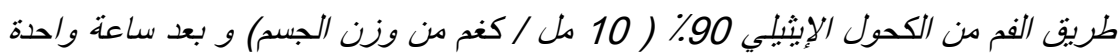

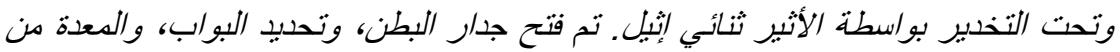

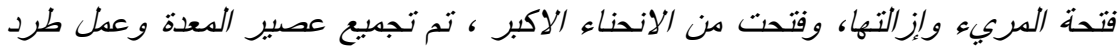

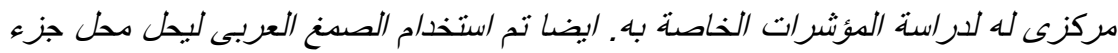

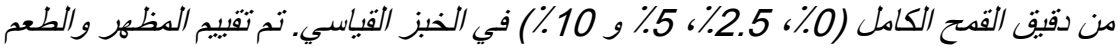

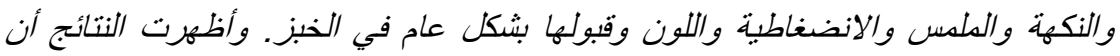

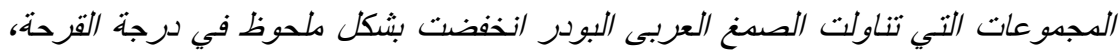

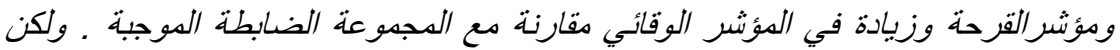

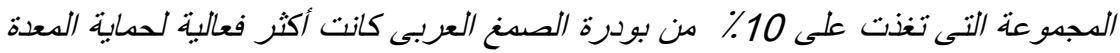

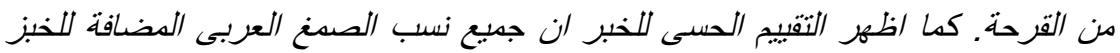

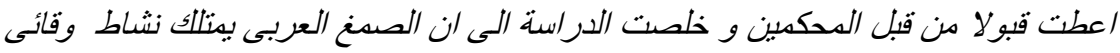

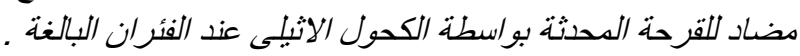

الكلمات الافتتاحية : : بودرة الصدغ العربى- قرحة المعدة - الكحول الاثبلى - العصبر

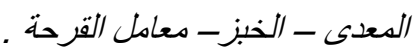

